\title{
OS MANUSCRITOS ECONOMICO-FILOSÓFICOS DE 1844 DE KARL MARX: dificuldades para publicação e interpretações críticas ${ }^{1}$
}

\author{
Marcello Musto* (https://orcid.org/0000-0003-0911-5907)
}

\begin{abstract}
Os Manuscritos econômico-filosóficos de 1844 constituem um dos escritos de Karl Marx mais célebres e difundidos em todo o mundo. Todavia, este texto, tão debatido e tão presente nos debates marxistas permaneceu desconhecido por muito tempo. As leituras instrumentais, que um e outro grupo fizeram sobre os Manuscritos econômico-filosóficos de 1844, são um claro exemplo de como a obra de Marx tenha sido constantemente objeto de conflitos teórico-políticos. Para melhor evidenciar tal realidade, o segundo e o terceiro parágrafo deste artigo reconstroem as dificuldades editoriais ligadas à sua publicação. Os parágrafos quarto, quinto e sexto apresentam, no entanto, uma breve resenha. Uma análise filológica dos Manuscritos econômico-filosóficos de 1844 foi desenvolvida no sétimo e oitavo parágrafos, tendo por base a nova edição históricocrítica MEGA. Na conclusão, segue uma tabela que reconstrói a cronologia da elaboração dos manuscritos e dos cadernos de extratos do período.
\end{abstract}

Palavras-chaves: Manuscritos Econômico-Filosófico de 1844, Jovem Marx, Marxismo, Alienação, MEGA.

\section{INTRODUÇÃO}

Os Manuscritos econômico-filosóficos de 1844 constituem um dos escritos de Karl Marx mais célebres e difundidos em todo o mundo. Todavia esse texto, tão debatido e tão presente nos debates marxistas, pela exaustiva interpretação da concepção de seu autor, permaneceu desconhecido por muito tempo. Na verdade, de sua redação a quando foi publicado, passou-se quase um século.

A publicação, ocorrida em 1932, não pôs fim, no entanto, às dificuldades. Com ela, iniciou-se a longa discórdia relacionada a seu caráter. Os Manuscritos econômico-filosóficos de 1844 eram escritos que expressavam concepções típicas da esquerda hegeliana, portanto, ainda pouco desenvolvidos se forem relacionados à crítica da economia política que Marx desenvolveu em seguida? Ou eles repre-

* Associate Professor of Sociological Theory. Department of Sociology.

2060 Vari Hall. York University. 4700 Keele Street. Toronto, ON, Canada M3J 1P3. marcello.musto@gmail.com

1 Tradução do italiano por Margareth Nunes, professora da Faculdade de Letras da UFG. Revisão Técnica: David Maciel. sentavam a base filosófica do pensamento de Marx, que permeia toda sua obra e que foi se enfraquecendo durante o longo período de elaboração de $O$ Capital? Esse conflito interpretativo teve valor político. A primeira interpretação foi sustentada pelos estudiosos soviéticos de Marx e por grande parte dos intérpretes que tinham um forte vínculo com os partidos comunistas ligados ao chamado "bloco socialista" ou que faziam parte dele. A segunda, no entanto, foi apresentada pelos protagonistas de um marxismo crítico, que encontraram, exatamente nesse texto, as fontes textuais e as mais eficazes argumentações (em particular, o conceito de alienação) para romper o monopólio que a União Soviética tinha adquirido, até então, sobre a obra de Marx.

As leituras instrumentais que um e outro grupo fizeram sobre os Manuscritos econômico-filosóficos de 1844 constituem um claro exemplo de como a obra de Marx tem sido constantemente objeto de conflitos teórico-políticos e frequentemente manobrada em razão desses interesses, com interpretações distorcidas. Para melhor evidenciar tal realidade, a segunda e a terceira parte deste artigo recons- 
troem as dificuldades editoriais ligadas à sua publicação. Nas quarta, na quinta e na sexta seçã, apresenta-se uma breve resenha - considerando os volumes escritos por tantos intérpretes desse texto - com suas interpretações. Uma breve análise filológica dos Manuscritos econômico-filosóficos de 1844 é desenvolvida nas sétima e na oitava partes, tendo por base a nova edição histórico-crítica MEGA², e são apresentadas algumas indicações sobre a necessidade de se lançar uma nova edição italiana desse texto. Na conclusão, segue uma tabela que reconstrói a cronologia da elaboração dos manuscritos e dos cadernos de extratos do período (outono de 1843 a janeiro de 1845).

\section{AS DUAS EDIÇÕES DE 1932}

A primeira publicação parcial dos $M a$ nuscritos econômico-filosóficos de 1844 foi feita em língua russa, sob a responsabilidade de David Borisoviĉ Rajazanov. Em 1927, na verdade, no meio do terceiro volume do Archiv K. Marksa i F. Engel'as, o famoso estudioso de Marx, na época diretor do Instituto Marx-Engels (IME) de Moscou, publicou grande parte do que viria a ser denominado "terceiro" manuscrito, ${ }^{2}$, com o título Trabalhos preparatórios F para a "Sagrada Família" (Marx, 1927). ${ }^{3} \mathrm{O}$ texN. to foi precedido de uma introdução do próprio $\stackrel{\circ}{i} \mathrm{Rja}$ Rjazanov, que destacou a importância do período no qual foram escritos esses manuscritos, caracterizado por um rapidíssimo avanço teórico de seu autor. Segundo o estudioso russo, o valor das notas publicadas era excepcional, i. pois, longe de representarem uma mera curio¿ sidade bibliográfica, elas constituíam uma స్ et etapa importante do caminho de Marx e per$\dot{s}$ mitiam entender melhor seu desenvolvimento

${ }^{2} \mathrm{O}$ que foi preservado dos Manuscritos econômico-filosófi๙ cos de 1844 são três manuscritos (com 27 partes do primei-

T. ro, 4 do segundo e 41 do terceiro), aos quais se deve acres-

centar uma folha de 4 partes, que contém um prospecto do

último capítulo da Fenomenologia do Espírito de Georg W.

F. Hegel, inserido por Marx no terceiro manuscrito.

${ }^{3}$ Os títulos das obras em russo foram traduzidos pelo autor diretamente no texto e citados em transliteração em nota. intelectual (Cf. Marx, 1927). ${ }^{4}$ Não obstante o grande rigor dos estudos feitos por Rjazanov, essa hipótese interpretativa se revelou equivocada. As indicações de Marx e o conteúdo das páginas dos Manuscritos econômico-filosóficos de 1844 testemunham que eles foram, de fato, um estudo preparatório para A sagrada família, mas também um trabalho anterior e diferente, dedicado à sua primeira análise crítica da economia política. Em 1929, La Revue Marxiste publicou a tradução francesa desse texto, que apareceu em dois números diferentes e com títulos diferentes. No primeiro número, de fevereiro, apareceu uma parte intitulada Notes sur le communisme et la propriété privée (Notas sobre o comunismo e a propriedade privada), enquanto no quinto número, em junho, saiu a parte seguinte com o título Notes sue les besoins, la production et la division du travail (Notas sobre as necessidades, a produção e a divisão do trabalho) (Marx, 1929a,b). ${ }^{5}$ Os textos foram apresentados como fragmentos da obra de Marx do ano de 1844 e divididos em vários subtítulos, que os separavam em partes para simplificar a leitura do conjunto.

Ainda em 1929, na K. Marx - F. Engels Soĉinenija (Obras) (1928-1947), a primeira edição soviética das obras de Marx e Engels, foi feita uma segunda edição russa do texto. $\mathrm{O}$ manuscrito foi inserido no III tomo, da mesma forma fragmentária e com o mesmo título errado de 1927 (Marx, 1929c). Além disso, em 1931, a revista "Unter den Bannern des Marxismus" publicou a primeira versão em língua alemã do fragmento Kritik der Hegelschen Dialektik und der Philosopnie überhaupt (Crítica da dialética e em geral da filosofia de Hegel) (Marx, 1931). ${ }^{6}$

A primeira edição completa em língua alemã foi lançada em 1932. Na verdade, no

${ }^{4}$ A esse respeito veja também Albert Mesnil, Note sur le communisme et la propriété priée (1929).

5 Todos os títulos das obras ou artigos não traduzidos para o italiano aparecem no texto com o título original seguido pela tradução entre parênteses.

${ }^{6}$ Os títulos das obras dos autores estrangeiros incluídos neste artigo, assim como as citações delas retiradas, foram traduzidos pelo autor. 
mesmo ano, as versões publicadas foram duas, e tal circunstância ajudou a alimentar a confusão em relação ao texto. Os estudiosos socialdemocratas Siegfried Landshut e J. P. Mayer publicaram uma coletânea das obras juvenis de Marx em dois volumes, Der historische Materialismus. Die Frühschriften (O materialismo histórico. Os escritos juvenis) (Marx, 1932a), na qual também foram inseridos os Manuscritos econômico-filosóficos de 1844. Tal edição tinha sido antecipada no ano anterior por um artigo do próprio Mayer, que anunciava a edição de um importantíssimo "texto de Marx até então desconhecido" (Mayer, 1931, p 154-157).7 Nessa coletânea, no entanto, os manuscritos de Marx foram publicados só parcialmente e com diversas e graves imprecisões. $\mathrm{O}$ "primeiro" manuscrito não estava presente; o "segundo" e o "terceiro" foram publicados em total desordem; e foi ainda inserido um suposto "quarto" manuscrito, que era, de fato, somente o compêndio do capítulo final da Fenomenologia do Espírito de Hegel, sem qualquer comentário de Marx. Além do mais, a ordem das várias partes foi alterada (os manuscritos foram publicados na sequência III, II, IV) tornando sua compreensão ainda mais difícil. Mais grave ainda é que a tradução do original continha numerosos erros, e o título escolhido também foi definitivamente equivocado. O título Nationalökonomie und Philosopie. Über den Zusammenhang der Nationalökonomie MIT Staat, Recht, Moral,und bürgerlichem Leben (1844) (Economia política e filosofia. Sobre o vínculo da economia política com o Estado, o direito, a moral e a vida civil) não correspondia ao que afirmara Marx no prefácio: "poderá ser observado, no presente texto, que o vínculo da economia política com o Estado, o direito e a moral será levado em consideração apenas na medida que a própria economia política leva em consideração ex professo esses temas" (Marx, 1968, p. 3). Um último e importante detalhe: o

${ }^{7}$ As citações retiradas dos textos que não foram traduzidas para o italiano e que aparecem neste artigo são de responsabilidade do autor. texto foi acompanhado por pouquíssimas indicações filológicas, contidas no prefácio dos organizadores, que indicavam o provável período em que foram redigidos os manuscritos, no arco de tempo entre fevereiro e agosto de 1844. Inicialmente, o texto deveria ter sido publicado em uma única edição, com o título Über den Zusammenhang der Nationalökonomie mit der Staat, Recht, Moral, und bürgerlichem Leben nebst einer Auseinandersetzung mit der Hegelschen Dialektik und der Philosophie überhaupt (Sobre o vinculo da economia política com o Estado, o direito, a moral e a vida burguesa com uma disputa com a dialética hegeliana e a filosofia em geral), sob os cuidados de Mayer e de Friedrich Salomon, sendo o primeiro responsável pela parte interpretativa e o segundo pela parte editorial.

No entanto, após a segunda revisão dos originais, o texto foi inserido na coletânea anteriormente citada, sob os cuidados do próprio Mayer e de Landshut (Cf. Landshut; Mayer, 1932a). Não obstante os graves erros editoriais e interpretativos até agora expostos, essa versão foi bastante divulgada na Alemanha e foi a base da tradução francesa, feita em 1937 por J. Molitor.

A segunda versão dos Manuscritos econômico-filosóficos de 1844, publicada em 1932, apareceu no terceiro volume da primeira seção da edição das obras completas de Marx e Engels, a Marx Engels Gesamtausgabe (MEGA), organizado pelo Instituto Marx-Engels de Moscou. Foi a primeira edição integral e científica desse texto, ao qual foi dado o título que se tornou célebre posteriormente: Ökonomisch-philosophische Manuskripte aus dem Jahre 1844 (Marx, 1932b). Pela primeira vez, os manuscritos foram publicados na disposição exata, e os originais foram traduzidos de modo acurado como não tinham sido na edição realizada na Alemanha. Uma introdução, embora muito circunscrita, reconstruiu a gênese do texto, e cada manuscrito foi precedido por uma breve descrição filológica. Mais precisamente, no volume, havia o subtítulo Para a crítica da 
economia política. Com um capítulo exclusivo sobre a filosofia hegeliana, os três manuscritos ficaram com os seguintes subtítulos: I. Salário - exploração do capital - Renda fundiária - Trabalho estranhado; II. A relação da propriedade privada; III. Propriedade privada e trabalho - Propriedade privada e comunismo - Necessidade, produção e divisão do trabalho - Dinheiro - Crítica da dialética e, em geral, da filosofia de Hegel. O "quarto manuscrito", como era chamado, que continha os excertos de Hegel, foi publicado em um apêndice com o título Excertos de Marx do último capítulo da 'Fenomenologia do espírito' de Hegel. ${ }^{.}$

Todavia, também os editores da MEGA, tendo de dar nome a esses manuscritos, colocando um prefácio no início do texto (na verdade, se encontra no terceiro manuscrito) e de reorganizar o conjunto, deram a entender que Marx teria tido, desde o princípio, a ideia de escrever uma crítica da economia política e que os manuscritos seriam uma obra originariamente dividida em capítulos (Cf. Rojahn, 1983, 2002). Particularmente significativa, nessa edição, foi, no entanto, a publicação dos cadernos de anotações de Marx. Desde o período universitário, na verdade, ele tinha adquirido o hábito, que manteve por toda a vida, de colocar em cadernos os resumos dos livros que

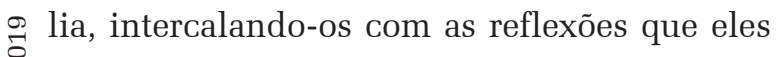
N suscitavam. Aqueles relativos ao período pari-

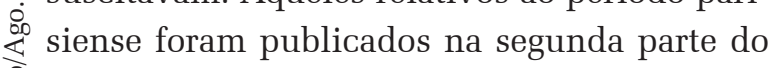
volume apresentado como Aus den Exzerptheften. Paris, anfang 1844 - Anfang 1845 (Dos cadernos de resumos. Paris, início de 1844 - início de 1845) e incluíram os resumos, até então inéditos, das obras de Friendrich Engels, Jean Baptiste Say, Fréderic Skarbek, Adam Smith, i David Ricardo, James Mill, John R. MacCulloch, Antoine L. C. Destutt de Tracy e Pierre de Boisguillebert. Essa edição apresentou ainda a descrição dos nove cadernos e um índice alfabético de todas as obras compendiadas (Cf. Marx, 1932b). Os intérpretes de Marx assumiram, no entanto, a tese, inexata, segundo a ${ }^{8}$ Tradução livre do autor. qual ele tinha redigido esses textos somente após ter lido e compendiado as obras de economia política (Cf. McLellan, 1974). Na realidade, o processo de redação se desenvolveu de modo alternado entre grupos de manuscritos e resumos (Cf. Lapin, 1974). Aliás, esses últimos intercalaram toda a produção parisiense, dos ensaios escritos para o Deustsch-französiche Jahrbücher até A sagrada família.

Em todo caso, a edição da MEGA se apresentou como a melhor e se tornou a base de grande parte das traduções que se seguiram. As duas diferentes versões publicadas em 1932 entravam em conflito, não só por algumas questões de filologia. Com o passar dos anos, o confronto entre "marxismo ocidental" e "marxismo soviético" foi se tornando sempre mais áspero, e a interpretação dos Manuscritos econômico-filosóficos de 1844 se apresentou como um dos principais objetos da disputa. Victor Adoratskij, o diretor da MEGA - substituto de Rjazanov em 1931, após os expurgos de Stalin, que também atingiram o IME, o qual, nesse meio tempo, tinha se tornado o Instituto Marx-Engels-Lenin (IMEL), - apresentou o texto como um escrito fragmentário, cujos temas eram o salário, a exploração do capital, a renda fundiária e o dinheiro, no qual Marx tinha elaborado uma análise da estrutura econômica do capitalismo recorrendo ainda à terminologia filosófica feuerbachiana (Cf. Adoratskij, 1932). Por outro lado, Landshut e Mayer ${ }^{9}$ escreveram uma obra que, "na essência, antecipa[va] já $O$ Capital", e que era, "em um certo sentido, a obra central de Marx, [que] forma[va] o fulcro de todo seu desenvolvimento conceitual" (Landshut; Mayer, 1932a, p. 33-38) e que não apenas devolvia ao leitor a terminologia filosófica marxiana dos primeiros escritos, mas expressava também a necessidade de reconduzir as teorias econômicas subsequentes aos conceitos desenvolvidos durante esse período. Ou seja: explicitava o conteúdo filosófico da

${ }^{9} \mathrm{~A}$ introdução assinada pelos dois organizadores, na verdade, foi feita somente por Landshut, que também a publicou como opúsculo, em separado (Cf. Landshut, 1932). 
teoria econômica da maturidade. Não obstante a ausência de fundamento, essa interpretação obteve grande sucesso e pode ser atribuído exatamente a esse ensaio o nascimento - facilitado, posteriormente, por muitos, como Louis Althusser, que não compartilhavam essa tese - da invenção do “jovem Marx”.

\section{TRADUÇÕES E PUBLICAÇÕES POSTERIORES}

Graças à sua superioridade filológica, a versão MEGA se destacou particularmente, e quase todas as traduções que apareceram depois se basearam nela - no Japão, em 1946, na Itália, em 1949, sob os cuidados de Norberto Bobbio, e, em 1962, também na França, após a versão filologicamente pouco confiável de 1937, citada anteriormente.

A melhor qualidade da edição MEGA foi reconhecida também pelo estudioso e teólogo evangélico Erich Thier, na introdução à reedição alemã organizada por ele em 1950 (Marx, 1950). Todavia sua nova edição dos Manuscritos econômico-filosóficos de 1844 acabou sendo um híbrido das duas primeiras versões, na qual algumas partes da versão MEGA se alternavam com outras provenientes daquela organizada por Landshut e Mayer, levando, assim, à produção de maiores mal-entendidos. O texto publicado, na verdade, foi o da MEGA, mas - como tinham já feito anteriormente os estudiosos - Thier decidiu não inserir o "primeiro" manuscrito. Da edição MEGA foram retomadas muitas notas explicativas referentes ao texto, mas Thier conservou também as imprecisões de Landshut e Mayer como, por exemplo, a convicção de que o "Prefácio" estaria colocado no "primeiro" e não no "terceiro" manuscrito. No que se refere ao título, por fim, manteve-se a escolha errada dos estudiosos alemães. Deve-se ressaltar que tais erros continuaram sendo repetidos, mesmo em publicações feitas duas décadas após a edição MEGA.

Em 1953, dessa vez sob a responsabi- lidade somente de Landshut, foi publicada a versão de 1932, com o novo título de Ökonomische-philosophische Manuskripte (1844). Os erros de 1932 foram repetidos, e as únicas alterações se referem à substituição de algumas traduções do original, que estavam erradas, com base na edição MEGA. Dois anos depois, surge a coletânea K. Marx - F. Engels. Kleine ökonomishe Schriften (Marx, 1953) (Breves escritos econômicos), que apresentou os $\mathrm{Ma}$ nuscritos econômico-filosóficos de 1844 sem o capítulo final sobre a "Crítica da dialética e em geral da filosofia de Hegel”. Além do mais, o texto foi revisado, sem algumas imprecisões contidas na versão MEGA de 1932.

Paralelamente aos limites dessas novas edições alemãs - que representaram, todas, um retrocesso em relação àquela da MEGA -, deve-se ressaltar a grande "perseguição" sofrida pelos Manuscritos econômico-filosóficos de 1844 na União Soviética e, mais amplamente, no Leste da Europa. Em 1954, o Instituto para o Marxismo-Leninismo (IML) de Moscou, nova denominação do IMEL, diante da preparação da nova edição russa das obras de Marx e Engels (K.Marx - F.Engels Soĉinenija), decidiu não incluir, em seus volumes, os manuscritos incompletos dos "fundadores do socialismo científico", ou seja, muitos daqueles importantíssimos trabalhos, graças aos quais teria sido possível uma mais correta interpretação da gênese do pensamento de Marx. Dentre os textos idosexcluídos, havia não somente os Manuscritos econômico-filosóficos de 1844, mas também as Linhas fundamentais da crítica da economia política, mais conhecidos como Grundrisse. Tal escolha editorial foi, porém, muito contraditória. Nessa edição, de fato, foi dado espaço para outros manuscritos de Marx, dentre eles os trabalhos juvenis - Sobre a crítica hegeliana do direito, inserida no primeiro volume, e $A$ ideologia alemã, que ocupou todo o terceiro volume. Ainda nessa "segunda" Soĉinenija (1955-66), havia um número maior de textos do que na primeira (1928-47), e a decisão de não publicar os Manuscritos econômi- 
co-filosóficos de 1844 revelou uma clara intenção de censura.

Eles apareceram, no entanto, como publicação individual, intitulada Excertos das obras juvenis (Marx; Engels, 1955) com uma impressão de somente 60.000 exemplares, em 1956 (Marx; Engels, 1956). Para que os Manuscritos econômico-filosóficos de 1844 fossem inseridos na "segunda" Soĉinenija, foi preciso aguardar quase vinte anos, ou seja, a publicação do volume anexo XLII ocorreu em 1974 (Cf. Brouchlinski, 1960). A preparação dessa edição exigiu um novo processo de verificação das fotocópias dos originais (que eram mantidos no Internationaal Instituut voor Social Geschiedenis, IISG, de Amsterdam, onde estão guardados dois terços do Nachlas de Marx e Engels). Tal escolha se revelou fundamental, pois permitiu realizar um grande número de correções não secundárias da versão MEGA de 1932. Por exemplo, a frase contida na última linha do "segundo" manuscrito, anteriormente traduzida como "Kollision wechselseitiger Gegensätze”, foi corretamente traduzida como "Feindlicher wechselseitiger Gegensatz". Em muitas partes, foi modificada a palavra "Genus", no lugar da "Geist" (Marx; Engels, 1974). Procedeu-se, por fim, à correção dos erros cometidos por Marx. Serve de exemplo a citação de Smith "Von den drei primitiven Klassen”, corretamente usada nos cadernos de N. resumos, mas errada nos Manuscritos econômico-filosóficos de 1844, onde aparecia como "Von den drei produktiven Klassen”. ${ }^{10}$ Além do mais, todas as citações feitas por Marx, muito longas, especialmente no "primeiro" manuscrito, foram publicadas com uma fonte menor, para facilitar ○. a identificação da paternidade das várias partes

С. $10 \mathrm{Na}$ versão italiana de Bobbio, ao contrário, foi mantida ๗ै a primeira transcrição errada, traduzida como "colisão de

$>$ oposições recíprocas” (Cf. Marx, 1968, p. 97). O mesmo

ثี ocorre na versão feita por Della Volpe nas Obras, onde a

- expressão foi traduzida como "colisão de recíprocas opo-

sições" (Cf. Marx, 1976). A tradução correta seria: "adver-

๙ sários de recíproca oposição”. A correção do termo Genuss

(gozo) no lugar de Geist (espírito), no entanto, é mostrada

Ty por Bobbio, que inclui também as correções de Selten (ra-

ช ramente) no lugar de selber (mesmo) e Prinzip (princípio)

no lugar de Progress (progresso). A propósito, ver a nota

à tradução da p. 18. Na sua versão, presente nas Obras,

Dalla Volpe optou por outra tradução para o termo Genuss, que, em português, ficou como "fruição". e para não atribuírem a ele frases que, na verdade, eram citações de outros autores. ${ }^{11}$

Assim como para a edição soviética, também a coletânea dos escritos de Marx e Engels publicada na República Democrática Alemã, a Marx Engels Weke (Obras) (MEW), lançada em 39 volumes entre 1956 e 1968, excluiu os Manuscritos econômico-filosóficos de 1844 do grupo de volumes numerados. Eles, na verdade, não foram inseridos no volume 2, publicado em 1962, onde deveriam ter sido colocados por razóes cronológicas, tendo sido publicados somente em 1968, como volume anexo (Ergänzungsband) (Cf. Brouchlinski, 1960). Tal volume, depois de ter aparecido com esse formato até 1981, em quatro edições sucessivas, foi publicado em 1985, com o título Schriften und Briefe, November 1837 - August 1844 (Escritos e Cartas, de Novembro de 1837 a Agosto de 1844), como o tomo 40 da MEW. A edição publicada foi a versão MEGA de 1932, com o acréscimo das correções feitas às traduções dos originais e pelo aparato crítico da edição Kleine ökonomische Schriften de 1955.

Após a MEGA de 1932, a primeira edição das obras de Marx publicada no "campo socialista" a inserir os Manuscritos econômico-filosóficos de 1844 nos seus volumes numerados foi a Marx-Engels-Gesamtausgabe $\left(\mathrm{MEGA}^{2}\right.$ ). Sua publicação começou em 1975, e os manuscritos parisienses foram impressos no volume $\mathrm{I} / 2$, em 1982, exatamente 50 anos após a primeira publicação. Nestsa nova forma, surgiu uma edição histórico-crítica, e os manuscritos foram publicados em até duas versões:. Uma primeira (Erste Wiedergabe) reproduziu a organização dos papéis originais de Marx e propôs, então, uma divisão em colunas de partes do texto do "primeiro" manuscrito. Uma segunda (Zweite Wiedergabe), no entanto, utilizou a divisão em capítulos e a paginação adotada por todas as edições anteriores (Marx; Engels, 1968). Foram acrescentados outros me-

${ }^{11}$ Ver MEGA I/3 (1932, p. 472, linha 2) e MEGA I/3 (1932, p. 68, linha 19). Tradução italiana: "das três classes elementares" e "das três classes produtivas". 
lhoramentos à tradução dos originais, dessa vez com particular atenção ao Prefácio (Marx-Engels-Gesamtausgabe, 1982). Confirmando as dificuldades de se realizar uma classificação entre os vários manuscritos marxianos (diante também de alguns limites postos pela edição $\mathrm{MEGA}^{2}$ ), o prospecto do capítulo final da $\mathrm{Fe}$ nomenologia do Espírito de Hegel foi inserido, tanto nesse volume como no IV/2, contendo os cadernos de resumos do período. ${ }^{12}$ Em 1981, de fato, a MEGA² tinha publicado também os cadernos com os resumos parisienses, alguns dos quais (aqueles das obras de Carl W. C. Schüz, Friendrich List, Heirnrich F. Osiander, Guillaume Prevost, Senofonte, Eugene Buret) não tinham sido publicados na primeira MEGA, sendo editados pela primeira vez. A publicação dos Pariser Hefte foi completada, por fim, com o volume IV/3 de 1998, que incluiu os compêndios marxianos referentes à Jean Law, a um manual de história romana de autoria incerta e àqueles referentes a James Lauderdale.

Com a $\mathrm{MEGA}^{2}$, os Manuscritos econômico-filosóficos de 1844 e todos os cadernos de resumos de 1844 foram publicados na íntegra. Todavia, antes de desenvolver algumas considerações filológicas a esse respeito, é útil retornar às principais interpretações críticas surgidas em relação a eles.

\section{UM OU DOIS MARX? A disputa sobre a "continuidade" do pensamento de Marx}

As duas edições de 1932 e as duas diferentes interpretações que as acompanharam deram início a uma multiplicidade de controvérsias, de caráter hermenêutico e, naturalmente, também político, do texto marxiano. Por um lado, como si viu, houve a interpretação voltada a entender esse texto como a ex-

${ }^{12}$ Segundo os organizadores da nota de introdução do volume $\mathrm{I} / 2$, houve "correções essenciais relativas às edições até então publicadas” ver $\mathrm{MEGA}^{2} \mathrm{I} / 2$, p. 35. Para todas as informações relativas às novas traduções, deve-se consultar a lista das variantes da Vorrede, incluído no volume $\mathrm{MEGA}^{2} \mathrm{I} / 2$, p. 842-852. pressão de uma fase juvenil, ainda negativamente condicionada pela impostação filosófica (Adoratskij). Por outro lado, ao contrário, houve aquela que entrevê, exatamente na elaboração filosófica do primeiro Marx, a essência de toda a sua teoria crítica e a expressão mais elevada de seu humanismo (Landshut e Mayer). As duas teses colocaram no centro do debate a questão da "continuidade": havia dois Marx diferentes entre si - um jovem e um maduro -, ou existiu um único Marx que, não obstante o passar dos anos, tinha substancialmente conservado suas convicções?

A oposição entre essas duas correntes foi se radicalizando cada vez mais. Em torno da primeira se juntou a ortodoxia stalinista e alguns outros, na Europa Ocidental, que compartilhavam os mesmos princípios oteóricos e políticos e que minimizaram ou rejeitaram totalmente a importância dos escritos iniciais, considerados superficiais se comparados às obras posteriores (Cf. McLellan, 1998). ${ }^{13}$ Para a segunda tese, apresentou-se uma realidade mais variada e heterogênea de autores, e todos tinham como denominador comum a rejeição ao dogmatismo do "comunismo oficial" e queriam romper a suposta relação direta que os expoentes desse último estabeleciam entre o pensamento de Marx e a realidade política da União Soviética.

As afirmações de dois protagonistas do debate marxista daquele período evidenciam, mais do que qualquer outro comentário, a importância da questão. Segundo Louis Althusser (1967, p. 35-37):

O debate sobre as obras juvenis de Marx é, antes de mais nada, um debate político. É preciso repetir que as obras juvenis de Marx [...] foram exumadas pela social democracia e exploradas contra as posições teóricas do marxismo-leninismo? [...] Eis, pois, o campo da discussão: o jovem Marx. A posição: o marxismo. Os termos: se o jovem Marx já é completamente Marx.

Iring Fetscher (1969, p. 312), no entanto afirmou:

${ }^{13}$ Ver MEGA $^{2}$ I/2 e MEGA² IV/2 (1981). 
Nos escritos juvenis de Marx, a libertação do homem de toda forma de exploração, de domínio e de alienação tem uma importância tão central, que, na época do domínio staliniano, um leitor soviético teria tomado estes argumentos exatamente como uma crítica à sua situação. Por esta razão, os escritos juvenis de Marx nunca foram publicados em russo em edições baratas e de grande tiragem. Eles eram considerados como trabalhos relativamente pouco significativos daquele jovem hegeliano que ainda não chegara ao marxismo, que seria, então, Marx.

Nessa contenda, ambas as partes distorceram o texto de Marx. Os ortodoxos negaram o valor dos Manuscritos econômico-filosóficos de 1844, chegando a censurá-los e a excluí-los das edições dos textos de Marx e Engels. As leituras do chamado "marxismo ocidental", ao contrário, conferiram - de maneira evidentemente forçada - a esse primeiríssimo esboço incompleto de Marx, um valor superior ao da obra que fora publicada após vinte anos de estudos e pesquisas: $O$ capital.

Nesse confronto ideológico, porém, quase todos os autores se comportaram do mesmo modo e consideraram os Manuscritos econômico-filosóficos de 1844 como um texto completo, orgânico e coerente, como uma verdadeira obra. Desse modo, apesar de incompletos e com a forma fragmentária que os caracterizava, eles foram lidos sem que se desse muita İ importância aos problemas filológicos neles presentes, que foram ignorados ou considera$\dot{8}$ dos pouco importantes (Rojahn, 1983).

Não é possível aqui dar um relato completo da vasta literatura crítica sobre os $\mathrm{Ma}$ nuscritos Econômico-Filosóficos de 1844. Em vez disso, vamos nos concentrar nos principais i. $\infty$

\section{AS PRINCIPAIS INTERPRETAÇÕES}

Logo após a publicação das duas versões de 1932, numerosos estudiosos se debruçaram sobre os Manuscritos econômico-filosóficos de 1844. Os autores alemães Henri de Man e Her- bert Marcuse chegaram a conclusões análogas àquelas de Landshut e Mayer.

O primeiro sublinhou que o texto parisiense já continha as avaliações sobre as quais Marx havia fundado todo o seu projeto teórico subsequente e avançou a hipótese de que Marx estava presente nos dois marxismos - o humanista da juventude e o da maturidade - e que o primeiro era superior ao segundo, esse último atingido pelo declínio das energias criativas (Cf. Man, 1932). Marcuse sustenta ainda a tese de que os Manuscritos econômico-filosóficos de 1844 evidenciavam os fundamentos filosóficos da crítica da economia política (Cf. Marcuse, 1975). Além do mais, naem sua opinião, a descoberta de uma presença assim tão forte da filosofia hegeliana no pensamento de Marx enriquecia a sua antropologia decom uma dimensão histórico-social ausente em Ludwig Feuerbach (Cf. Marcuse, 1997).

A descoberta da importância do "jovem Marx" decorreu, cada vez mais, dos estudos de sua relação com Hegel, e, tal circunstância, foi favorecida pela publicação, ocorrida um pouco antes daquela dos Manuscritos econômico-filosóficos de 1844, dos manuscritos de Jena de Hegel (Cf. Hegel, 1923, 1931). Um dos principais autores que empreendeu estse percurso foi György Lukács, quando, em seu texto de 1923, História e consciência de classe, surpreendentemente tinha antecipado muitos dos temas do futuro debate hegelo-marxiano. No seu livro de 1938, O jovem Hegel e os problemas da sociedade capitalista, Lukács (1950 ${ }^{14}$ estabeleceu uma relação entre estudos juvenis dos dois autores - sendo que os de Marx eram filosóficos e os de Hegel eram econômicos - e estabeleceuidentificou as afinidades que havia encontrado neles. Em particular, ele destacou que as referências marxianas sobre Hegel, nos Manuscritos econômico-filosóficos de 1844, estavam presentes muito além das passagens

${ }^{14}$ O testemunho autobiográfico de Lukács (1971a, p. 57) em relação à leitura dos Manuscritos econômico-filosóficos do ano 1844 é muito importante: "lendo os manuscritos, mudei completamente a minha relação com o marxismo e transformei a minha perspectiva filosófica”. 
nas quais ele fora citado textualmente. Na sua opiniãoEm sua opinião, diversas análises econômicas tinham sido motivadas pela crítica da concepção filosófica hegeliana:

... a conexão entre economia e política é [...], nestes manuscritos de Marx, uma clara necessidade metodológica, a condição de uma efetiva superação da dialética idealista de Hegel. Por isso seria superficial e extrínseco acreditar que o debate de Marx com Hegel comece somente na última parte do manuscrito, que contém a crítica da Fenomenologia. As partes anteriores, puramente econômicas, em que Hegel nunca é lembrado diretamente, contêm o fundamento mais importante deste debate e desta crítica: o esclarecimento econômico dos principais fatos do estranhamento. (Lukács, 1950, p. 760). ${ }^{15}$

Nas aulas sobre a Fenomenologia do espírito, dadas na École Pratique des Hautes Études de 1933 a 1939 e, depois, reunidas e publicadas por Raymond Queneau no livro Introdução à leitura de Hegel, Alexandre Kojève (1996) - outro autor destinado a exercer grande influência - aprofundou essa relação, embora a sua leitura da obra de Hegel tenha sidofoi feita à luz da interpretação marxiana. $\mathrm{O}$ vínculo entre Hegel e Marx foi desenvolvido, por fim, também por Karl Löwith no célebre e muito difundido texto De Hegel a Nietzsche (Löwith, 1949).

Associados ao vínculo com Hegel, sempre na República Federal da Alemanha, após a segunda guerra mundial, textos como Die Anthropologie dês jungen Marx nach den Pariser ökonomisch-philosophischen Manuskripten (A antropologia do jovem Marx nos manuscritos econômico-filosóficos de Paris) de Erich Thier (1950), Der entfremdete Mensch (O homem alienado) de Heinrich Popitz (1967) e O Eros da técnica, de Jacob Hommes (1970) divulgaram a opinião de que os Manuscritos econômico-filosóficos de 1844 eram o texto fundamental de toda a obra marxiana. Pouco depois, surgiu, em toda a Europa, um grande interesse filosó-

${ }^{15}$ Ver Georg W. F. Hegel, Jenenser Logik, Metaphysik und Naturphilosophie, (organizado por G. Lasson), Felix Meiner, Leipzig 1923 e Georg W. F. Hegel, Jenenser Realphilosophie, (organizado por J. Hoffmeister), 2 v., Felix Meiner, Leipzig 1931. fico por Marx. A França foi, sem dúvida, o país onde esses estudos proliferaram e se difundiram e no qual o pensamento juvenil de Marx foi colocado como a base da crítica filosófica e política, ao contrário do dogmatismo stalinista e do marxismo oficial (Cf. Faracovi, 1972). ${ }^{16} \mathrm{O}$ estudo dos textos juvenis de Marx foi, na França, "o evento filosófico decisivo daquele período” (Lefebvre, 1957, p. 114). Constituiu um processo variado, que caracterizou todos os 15 anos do pós-guerra francês, no qual muitos autores, diferentes entre si pela cultura filosófica e pelas tendências políticas, tentaram encontrar uma síntese filosófica entre marxismo, hegelianismo, existencialismo e cristianismo. O debate produziu muita literatura ruim, baseada mais nas convicções pessoais dos autores do que no texto marxiano, o que levou a verdadeiras distorções da obra de Marx. Os Manuscritos econômico-filosóficos de 1844 foram apresentados como o melhor texto de Marx e foram violentamente confrontados, em nome da sua presumível unicidade, ao pensamento posterior e, em particular, a $O$ capital, texto que - muito provavelmente - muitos desses autores não tinham estudado suficientemente.

Em Sentido e não sentido, de 1948, após estudar os Manuscritos econômico-filosóficos de 1844, e mediante a influência exercida pela leitura de Kojève, Maurice Merleau-Ponty declarou sua convicção de que o pensamento juvenil de Marx era existencialista (Cf. Merleau-Ponty, 1962). ${ }^{17}$ Poucos anos depois, Jean Hyppolite, em seus Ensaios sobre Marx e Hegel, um dos melhores livros dentre aqueles escritos naquele contexto, insistiu muito no vínculo entre os trabalhos juvenis e $O$ capital, sublinhando como a relação entre eles era exatamente Hegel. Ele colocou em evidência a

... necessidade, para a compreensão de $O$ capital, de fazer referência às obras filosóficas anteriores,

${ }^{16}$ Ver Faracovi (1972, p. 9), em particular as páginas 12 a18, onde se destaca que "a cultura filosófica francesa do pós-guerra se interessou por Marx durante muito tempo, de maneira quase que exclusiva, na forma do pensamento juvenil”.

${ }^{17}$ Ver, em particular, o capítulo "Marxismo e filosofia". 
além dos estudos econômicos de Marx. - A obra de Marx pressupõe um substrato filosófico do qual nem sempre é fácil reconstituir os diferentes elementos. - Profunda influência de Hegel, que Marx conhecia profundamente. [...] Creio [...] que não se possa entender a obra essencial de Marx, ignorando as principais obras de Hegel, que contribuíram para a formação e o desenvolvimento do seu pensamento, a Fenomenologia do Espírito, a Lógica, a Filosofia do direito. (Hyppolite, 1963, p. 153, 155).

Os textos de Jean-Paul Sartre também seguiram nessa direção. Ao mesmo tempo, o Marx "filosófico" tornou-se também um Marx "teológico" (Cf. Langset, 1963). Na verdade, nas obras dos autores cristãos Pierre Bigo e Jean Yves Calvez, a primeira intitulada Marxismo e humanismo (Bigo, 1963) e a segunda $O$ pensamento de Karl Marx (Calvez, 1966), com base em uma interpretação particular dos $M a$ nuscritos econômico-filosóficos de 1844, o pensamento de Marx se revestiu sempre mais de valores éticos, devidos à religião cristã e com uma clara oposição às políticas da União Soviética. Roger Garaudy também demonstrou a presença de influências humanísticas nos primeiros textos de Marx e se colocou como suporte de um marxismo aberto ao diálogo com outras culturas, em particular com aquela cristã (Cf. Garaudy, 1969). Por fim, no panorama francês, teve grande importância a tradução,

^ ${ }^{18}$ Após a publicação de 1923, o autor húngaro reviu várias

ఈิ ticadas, nesse meio tempo, nos países ditos socialistas. A

7. mais importante correção feita foi assim resumida na nova

introdução escrita por ocasião da reimpressão de 1967:

๙ "História e consciência de classe segue Hegel na medida

ت em que, também nesse livro, a alienação é colocada no mesmo plano da objetivação (para usar a terminologia filosófica dos Manuscritos econômico-filosóficos do ano 1844 de Marx)" (Cf. Lukács, 1971b).

${ }^{19}$ Ao lado do já citado Jean Yves Calvez, $O$ pensamento de Karl Marx (1956), deve-se recordar Kostas Axelos, Marx goria foi o objeto central da principal controvérsia político-filosófica sobre Marx naqueles anos: estabelecer a relação que existia entre as teorias "juvenis" dos Manuscritos econômico-filosóficos de 1844 e aquelas da "maturidade", ou seja, de $O$ capital. Os vários autores se dividiram em três principais posições: 1) continuidade entre os Manuscritos econômico-filosóficos de 1844 e $O$ capital; 2) contraposição entre os Manuscritos econômico-filosóficos de $1844 \mathrm{e}$ O capital e superioridade teórica dos primeiros sobre o segundo; 3) importância limitada dos Manuscritos econômico-filosóficos de 1844, interpretados como uma etapa meramente transitória no processo de elaboração de Marx. ${ }^{20}$

A primeira posição pode ser sintetizada no reconhecimento de uma continuidade entre as teses dos Manuscritos econômico-filosóficos de 1844 e aquelas de O capital. Aos trabalhos já citados de Bigo e Calvez pode-se agregar, nessa linha de interpretação, o texto de 1957 de Maximilien Rubel, Karl Marx. Ensaio de biografia intelectual, e o de Erich Fromm, Marx's concept of Man. Segundo Rubel, com a categoria de trabalho alienado (entfremdete Arbeit) tem-se "a chave de toda a obra posterior do economista e do sociólogo [Marx]" e "a tese central de $O$ capital foi aqui antecipada" (Rubel, 2001, p. 130). Do mesmo modo, alguns anos depois, Fromm afirmou (1961, p. 54): “o conceito de alienação sempre [foi] e permaneceu o ponto central do pensamento do 'jovem' Marx que escreveu os Manuscritos econômico-filosóficos de 1844 e do 'velho' Marx que escreveu o Capital”. Outro importante livro que pode ser arrolado nessa linha de interpretação é Marx e o marxismo, publicado em 1967, na

pensador da técnica ([1961] 1963), Istvan Meszaros, A teoria da alienação em Marx (1970); Adam Schaff, A alienação como fenômeno social (1979), Giuseppe Bedeschi, Alienação e fetichismo no pensamento de Marx (1968) e Bertell Ollman, Alienation. Marx's conception of man in capitalist society (1971).

${ }_{20}$ Para uma breve resenha sobre o assunto, veja Ernest Mandel, A formação do pensamento econômico de Karl ([1967] 1970), em particular o capítulo X "Dos Manuscritos de 1844 aos Grundrisse: de uma concepção antropológica a uma concepção histórica da alienação". Uma análise das diferentes interpretações encontra-se também no muito citado Jürgen Rojahn, em $O$ caso dos chamados "manuscritos econômico-filosóficos do ano 1844". 
Alemanha ocidental, pelo estudioso alemão Iring Fetscher. O seu propósito, na verdade, foi exatamente o de demonstrar como:

... as categorias críticas que Marx tinha elaborado nos
seus Manuscritos de Paris e nos cadernos de resumos
constituem a base da teoria da economia política no
Capital e não foram de modo algum renegadas pelo
Marx 'adulto'. Com isso deveria estar provado que as
obras juvenis não apenas permitem entender quais
foram as motivações que levaram Marx a escrever a
crítica da economia política ( $O$ capital), mas que a
crítica da economia política contém, implicitamen-
te, e, em parte, explicitamente, a crítica à alienação e
à reificação, que constituem o tema central das obras
juvenis. (Fetscher, 1969, p. 30).

A tese da grande importância dos $M a-$ nuscritos econômico-filosóficos de 1844 também conquistou um marxista próximo aos cânones interpretativos soviéticos, Palmiro Togliatti, que - em uma contribuição publicada no volume XXX e inserida, em tradução para o francês, em uma importante coletânea de ensaios sobre o jovem Marx - afirmou que, nos Manuscritos econômico-filosóficos de 1844,

... foi aberta a estrada para a crítica de toda a sociedade burguesa, que será feita nos anos e nas obras seguintes e que culminará no Capital, mas pode-se dizer que em grande parte já está completa [...]. Apesar da sua forma, que não é simples, se nota que todo o marxismo já está contido aqui. (Togliatti, 1961, p. 48-49).

A segunda interpretação se baseou, ao contrário, na contraposição entre o "jovem" Marx e o "maduro" e na superioridade e maior riqueza teórica do primeiro em relação ao segundo. Os precursores dessa linha foram os já mencionados Landshut e Mayer, que, no prefácio da edição de 1932, tinham declarado que os Manuscritos econômico-filosóficos de 1844 eram a revelação do autentico marxismo: "em certo sentido a obra mais central de Marx", que contém "o ponto crucial do desenvolvimento do seu pensamento, onde os princípios da análise econômica derivam diretamente da idéia da "verdadeira realidade do homem"' (Landshut; Mayer, 1932a, p. 13). Comparti- lharam dessa leitura outros autores alemães, dentre os quais os já citados Henri De Man, Heinrich Popitz, Jacob Hommes - além de Erich Thier, no opúsculo de 1957 Das Menschenbild des jungen Marx (Their, 1957) (A visão de homem do jovem Marx). Análoga convicção foi apresentada por Kostas Axelos (1963, p. 56-57), que, na obra Marx pensador da técnica, afirmou: "o manuscrito de 1844 é e continua a ser o texto mais denso do pensamento, dentre todas as obras marxianas e marxistas".

A terceira posição, por fim, foi defendida por todos aqueles que consideravam os Manuscritos econômico-filosóficos de 1844 somente uma etapa transitória do pensamento de Marx. Nesse texto, que foi definido como de amadurecimento teórico, ele teria sido capaz de recolher as principais contradições da sociedade burguesa, mas com uma impostação ainda filosófico-humanista e uma linguagem influenciada pela obra de Feuerbach. Um dos principais limites dessa interpretação foi o de considerar as concepções juvenis de Marx em função dos futuros e já conhecidos desdobramentos de sua obra. Segundo essa leitura, a categoria de alienação já estava presente exclusivamente nas obras "juvenis", mas totalmente ausente nas obras da "maturidade". Enfim, os autores que sustentaram essa posição - principalmente os expoentes da ortodoxia "marxista-leninista" - consideraram que as etapas da evolução do pensamento de Marx foram as indicadas por Lênin, convicção que, além de ser, em muitos aspectos, discutível, não permitia levar em consideração a grande importância dos inéditos de 1932 publicados depois da morte do líder bolchevique.

Entre os expoentes mais importantes dessa escola interpretativa, podemos citar $\mathrm{Au}$ guste Cornu que, primeiramente em 1934, com a publicação de sua tese de graduação Karl Marx - L'homme et l'oeuvre. De l'hégélianisme au matérialisme historique (Cornu, 1934) (Karl Marx - O homem e a obra. Do hegelianismo ao materialismo histórico), primeiro embrião da sua futura obra em quatro tomos intitulada 
Marx e Engels ${ }^{21}$ ) colocou os Manuscritos econômico-filosóficos de 1844 no trilho da interpretação soviética. Vincularam-se também a ela o já citado ensaio de Jahn, o de Manfred Buhr (1966), publicado na prestigiosa revista da República Democrática Alemã Deustsche Zeitschrift für Philosophie, e as introduções às reedições do texto de Cornu (1968) e de Emile Bottigelli (1962). Mais tarde, Cornu, no terceiro volume de sua obra (Marx em Paris), considerada a biografia intelectual mais completa já escrita sobre essa fase da vida de Marx, evitou a comparação com outros escritos posteriores e se limitou a uma avaliação menos ideologizada do texto (Cornu, 1962a). ${ }^{22}$

Merece particular atenção, enfim, a obra de Althusser. A coletânea de ensaios publicada por ele em 1965, com o título A Favor de Marx, certamente representou o principal texto dessa polêmica, e estimulou o maior número de reações e discussões. Althusser sustentou que, em A ideologia alemã e nas Teses sobre Feuerbach, estava claramente presente uma ruptura epistemológica (coupure èpistémologique) ${ }^{23}$ "que constitui a crítica da sua antiga consciência filosófica (ideológica)” (Althusser, 1970, p. 16). Com base nessa cesura, ele subdivide o pensamento de Marx "em dois grandes períodos essenciais: o período ainda 'ideológico',

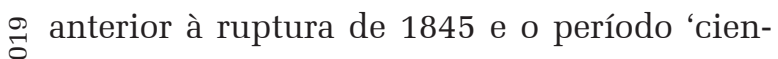
¿े. tífico', posterior à ruptura de 1845." (Althus$\dot{\infty}$ ser, 1970, p. 17). ${ }^{24}$ Também nesse caso, um dos principais pontos de divergência foi a relação entre Marx e Hegel. Para Althusser, na verdade, Hegel tinha inspirado Marx em um único

${ }^{21}$ Auguste Cornu, Marx e Engels ([1955] 1962). Os volumes $\dot{2}$ III e IV, que não foram traduzidos para o italiano e que, $\stackrel{0}{\circ}$ portanto, não foram incluídos nessa edição, foram publi- cados em Paris pela Presses Universitaires de France em д. 1962 e em 1970 .

${ }^{22}$ A esse respeito, veja, em particular, as pági$\therefore$ nas 172-177.

${ }^{23}$ A respeito do conceito de "ruptura epistemológica”, remete-se a Étiénne Balibar, Para Althusser, (1991), em particular o último capítulo "O conceito de "ruptura epistemoTógica’ de Gastón Bachelard a Louis Althusser”, p. 65-97.

${ }^{24}$ A “subdivisão" do pensamento de Marx realizada por Althusser foi articulada em quatro fases: as obras juvenis (1840-1844); as obras da ruptura (1845); as obras do amadurecimento (1845-1857); as obras da maturidade (18571883), (Althusser, 1970, p. 18). texto - os Manuscritos econômico-filosóficos de 1844 - e, portanto, no seu período "ideológico-filosófico": "o jovem Marx nunca foi hegeliano, mas, inicialmente, foi kantiano-fichtiano e, depois, foi feuerbachiano. A tese em grande voga do hegelianismo do jovem Marx, em geral, é um mito. Em compensação, às vésperas da ruptura com a anterior consciência filosófica” (Althusser, 1970, p. 18) é como se Marx, recorrendo pela primeira e única vez na juventude a Hegel, tivesse produzido uma extraordinária "aberração" teórica indispensável à eliminação da sua consciência "delirante" (Althusser, 1970). ${ }^{25}$

Desse modo, para Althusser, os Manuscritos econômico-filosóficos de 1844 são "o texto mais distante que existe, teoricamente falando, da aurora que estava para surgir" (Althusser, 1970, p. 19).

O Marx mais distante de Marx é justamente este Marx aqui, ou seja, o Marx mais próximo, o Marx da véspera, o Marx do limiar: como se, antes da ruptura, e para realizá-la, ele tivesse tido a necessidade de dar à filosofia todas as suas possibilidades, a última possibilidade, este império absoluto do seu contrário e este imenso triunfo teórico: ou seja, a sua derrota. (Althusser, 1970, p. 137).

A paradoxal conclusão de Althusser (1970, p. 65) foi a de que "não se pode absolutamente dizer que 'a juventude de Marx pertence ao marxismo’”. ${ }^{26}$ Dessa forma, sua posi-

${ }^{25}$ A esse respeito, é interessante o breve testemunho biográfico-intelectual sobre a relação entre Althusser e os Grundrisse, presente no recente texto de Lucien Sève, Penser avec Marx aujourd'hui. I. Marx et nous (2004). A propósito da velha polêmica sobre a presença ou não do conceito de alienação no $O$ capital, o estudioso francês nota como Althusser, com exceção da Introdução de 1857. nunca tenha lido os Grundrisse. Para maiores detalhes ver p. 29. Pode-se acrescentar ainda que os Grundrisse, o texto mais hegeliano do Marx maduro, foram escritos logo após a Introdução de 1857, considerada pelo filósofo francês a quintessência do método marxista maduro. A esse propósito, deve-se ver o capítulo "L'objet Du Capital" em Louis Althusser, Ler o Capital ([1965] 1971).

${ }^{26}$ Muito eficaz a esse respeito é a breve e polêmica referência de Maximilien Rubel sobre o "marxismo" de Althusser. Em uma breve nota de introdução a um dos volumes sobre Marx, publicados por ele na prestigiosa coleção Plêiade, Rubel declarou ironicamente que, com a sua afirmação, Althusser tinha dito somente uma "meia verdade [...] uma boa leitura das obras da maturidade conduz à verdade por inteiro, ou seja: Marx nunca, em nenhum momento de sua carreira, pertenceu ao marxismo." (Rubel, 1968, p. 63). 
ção, embora concebida por pontos de partida opostos, contribuiu, especularmente, com a de Landshut e Mayer, ou de outros autores franceses precedentemente já citados , para criar o mito do "jovem" Marx.

Essas concepções se basearam numa contraposição filologicamente infundada dos textos de Marx. Sem entrar, aqui, no mérito da polêmica relativa à presença ou não das categorias filosóficas juvenis e da influência hegeliana nas críticas da economia política de Marx, é preciso ressaltar um limite de grande parte dessas interpretações. Esse limite está em considerar os Manuscritos econômico-filosóficos de 1844 como uma obra concluída, um texto coerente, escrito de modo sistemático e pré-organizado. As tantas interpretações que quiseram atribuir a eles o caráter de uma orientação acabada, tanto aquelas que reconheciam neles a completude do pensamento marxiano (Landshut e Mayer ou os filósofos Frances) quanto as que os tinham como uma concepção definida e oposta àquela da maturidade científica (Althusser) foram refutadas pelo exame filológico.

Um dos primeiros autores que interveio a esse respeito foi Ernest Mandel, que, em seu texto de 1967, A formação do pensamento econômico de Karl Marx, disse que a razão do erro de Althusser se originava no seu "esforçar(se) em vão para apresentar os Manuscritos econômico-filosóficos de 1844 como o fruto de uma ideologia concluída 'pertencente a um todo"' (Mandel, 1973, p. 175).27 Para Mandel, os Manuscritos econômico-filosóficos de 1844 espelhavam a transição de Marx e, portanto, apresentavam, no seu interior, elementos típicos do passado e temas futuros, circunstância

${ }^{27}$ Ernest Mandel, A formação do pensamento econômico em Karl Marx, (1973). Segundo Mandel, Althusser “tem razão em se opor a todo método analítico-teleológico que conceba a obra juvenil de um determinado autor exclusivamente com o intento de saber até que ponto tenha-se aproximado ao ‘objetivo' constituído pela obra da maturidade. [Mandel se refere à crítica feita à "pseudoteoria da historia da filosofia no 'futuro anterior"'. Ver Louis Althusser, Para Marx, (1970, p. 38). Nota do Autor] Mas está errado em contrapor um método que secciona arbitrariamente em formações ideológicas coerentes, as sucessivas fases evolutivas de um mesmo autor, com o pretexto de considerar 'cada ideologia como um todo"” (Althusser, 1970, p. 175-176). que produzia diversas contradições. Com posicionamento similar a esse respeito, também se apresentava o precedente trabalho de Pierre Naville, Da alienação ao gozo (Naville, 1978).

\section{AS INTERPRETAÇÕES NO "CAMPO SOCIALISTA" NO MUNDO ANGLO- -SAXÃO E NA ITÁLIA}

Inicialmente, o marxismo oficial ignorou os Manuscritos econômico-filosóficos de 1844 ou foi totalmente incapaz de analisá-los com seriedade. Georg Mende, por exemplo, no seu texto Karl Marx' Entwicklung Von revolutionären Demokraten zum Kommunisten (O desenvolvimento de Karl Marx de democrático revolucionário a comunista), não fez referência a eles nem na primeira edição de 1954, nem na segunda edição de 1955. Somente na terceira edição, em 1960, ele admitiu que esses "trabalhos preparatórios de Marx [...] para uma obra maior" (Mende, 1960, p. 132) não podiam ser ignorados. Dessa forma, os escritos e as categorias juvenis de Marx que, no chamado "marxismo ocidental", ocuparam um lugar de destaque desde os anos trinta, por causa do dogmatismo staliniano e da hostilidade em relação ao conceito de alienação, estrearam no campo soviético com enorme atraso.

Ao lado dos pouquíssimos textos russos, a primeira publicação que difundiu, na Europa, um bom número de ensaios sobre os Manuscritos econômico-filosóficos de 1844 dos estudiosos soviéticos foi a coletânea Sur le jeune Marx (Sobre o jovem Marx), publicada em 1961 como número especial da revista $R e$ cherches Internationales à la lumière du marxisme. ${ }^{28}$ Aos textos dos russos O. Bakouradze,

${ }^{28}$ Outra interessante publicacão a respeito foi a coletânea em língua inglesa editada pela Academia das Ciências da União Soviética Philosophy, science and man. The soviet delegation reports for the XIIIth World Congress of Philosophy, Moscou (1963), assinala, em particular, o ensaio de T. I. Oiserman, Man and his alienation. Sobre temas análogos, em italiano, há A sociedade soviética e o problema da alienação. Uma polêmica entre E. M. Sitnikov e Iring Fetscher no Iring Fetscher, Marx e o marxismo: da Filosofia do proletariado à Weltanschaaung proletária (1969). 
Nikolai Lapin, Vladimir Brouchlinski, Leonide Pajitnov e A. Ouibo foram acrescentados artigos de alguns dos principais estudiosos de Marx da Polônia (Adam Schaff) e da República Democrática Alemã (Wolfgang Jahn e Joachim Hoeppner), além do texto de Togliatti, citado anteriormente. Mesmo com conotações da abordagem ideológica da época, esses textos constituem a primeira tentativa, do lado socialista, de se enfrentarem quanto às problemáticas relativas ao "jovem” Marx e de disputar o monopólio interpretativo com os marxistas “ocidentais" (Althusser, 1967, p. 35). Algumas contribuições apresentaram ideias interessantes, dentre elas o ensaio "Les manuscrits economico-philosopiques de 1844" de Pajitnov (1960, p. 98), no qual ele afirmava que

... as ideias fundamentais de Marx estão ainda por
vir, e juntamente a notáveis formulações, nas quais
está germinando uma nova concepção de mundo,
há também muitos pensamentos ainda não amadu-
recidos, que são marcados pela influência das fon-
tes teóricas que serviram de material para a reflexão
de Marx e das quais ele partiu para a elaboração da
sua doutrina.

A formulação teórica de base, sustentada por grande parte dos autores, estava, no entanto, errada. Contrariamente às interpretações em voga, que reliam os conceitos de $O$ capital $\stackrel{\sigma}{\sigma}$ através daqueles encontrados nos trabalhos $\stackrel{\sim}{\circ}$ juvenis, muitos destes estudiosos seguiram o percurso contrário: analisaram os textos juvenis a partir dos desenvolvimentos posteriores da teoria de Marx, ou seja, "ler os textos juvenis pelo filtro dos textos da maturidade" (Althusser, 1967, p. 41). O que veio antes do pensamento $\therefore$ de Marx impediu, assim, de captar o significado e o valor da elaboração daquele período.

Em seguida, no entanto, o estudo dos Manuscritos econômico-filosóficos de 1844 ganhou força também nos países socialistas e obteve alguns resultados relevantes. Dentre eles, deve-se destacar o trabalho de 1958, Die Entwicklung der ökonomischen Lehre Von Marx und Engels in den vierziger Jahren dês 19. Jahrhunderts (Rosenberg, 1958) (O desenvolvi- mento da doutrina econômica de Marx e Engels nos anos quarenta do século XIX), de D. I. Rosenberg. Despertou maior interesse, ainda Antes de O Capital, de Walter Tuchscheerer, sem dúvida o melhor estudo feito no Leste sobre o pensamento econômico do jovem Marx, que teve o mérito de examinar criticamente, além dos Manuscritos econômico-filosóficos de 1844, também o conteúdo dos principais cadernos de resumos parisienses (Althusser, 1967).

Aos Manuscritos econômico-filosóficos de 1844 foi reconhecido um papel relevante também no marxismo anglo-saxão. No entanto, também ali, o estudo desse texto foi iniciado tardiamente em relação a outros países. A primeira edição que despertou um interesse bastante amplo surgiu nos Estados Unidos, com a obra de Erich Fromm e com tradução de Tom Bottomore, lançada em 1961. O ensaio de introdução, também publicado no mesmo ano, no livro de Fromm, apresentou os Manuscritos econômico-filosóficos de 1844 como "o principal trabalho teórico de Marx”29 (Fromm, 1961, p. 5), e prevaleceram, de maneira difusa, os estudos que analisaram a influência hegeliana sobre o jovem Marx. Foi precursor, nesse aspecto, Sidney Hook, que, em 1933, com seu trabalho Towards an Understanding of Karl Marx (Hook, 1933) (Para uma compreensão de Karl Marx). Nos anos sessenta, foram publicados diversos volumes que apresentaram uma interpretação análoga. Dentre eles, os principais textos foram Philosophy \& Myth in Karl Marx (Tuchscheerer, 1980) (Filosofia e mito em Karl Marx), de Robert Tucker, e o livro, na verdade mais histórico-político do que filosófico, do estudioso israelita Shlomo Avineri O pensamento político e social de Marx (Fromm, 1961).

Não faltaram as opiniões contrárias, também nesse caso, até mesmo muito radicais. Segundo Daniel Bell, a insistente aproximação de Marx a Hegel nada mais era do que a "cria${ }^{29}$ Contra essa postura, é bom lembrar uma passagem de Althusser que é muito significativa: "Certamente nós sabemos que o jovem Marx se tornará Marx, mas não queremos viver mais depressa do que ele; não queremos viver no lugar dele, romper por ele ou descobrir por ele. Não o esperaremos à frente no final da corrida, para lançar sobre ele, como sobre um fundista, o manto do descanso,
porque, afinal de contas, chegou" (Althusser, 1967, p. 53). 
ção de um novo falso mito", pois "identificada na economia política a resposta aos mistérios de Hegel, Marx esqueceu-se totalmente da filosofia.” (Bell, 1959, p. 935, 944).

Quanto ao panorama italiano, por fim, deve-se destacar a influência da obra de Galvano della Volpe, especialmente de seu livro de 1956, Russeau e Marx, ao ressaltar que o mais importante, dentre os escritos juvenis de Marx, fora, durante muito tempo, a Crítica da filosofia hegeliana do direito público. Segundo Della Volpe (1971, p. 150), esse texto continha "as premissas mais gerais de um novo método filosófico", enquanto que os Manuscritos econômico-filosóficos de 1844 foram definidos como uma espécie de "confusão" econômico-filosófica. Uma das melhores análises dos manuscritos parisienses, porém, foi feita pouco depois. Entre 1960 e 1963, Mario Rossi publicou, em quatro volumes, o notável estudo De Hegel a Marx, e a parte final do terceiro tomo - A escola hegeliana. O jovem Marx (Tucker, 2001) - foi dedicada aos Manuscritos econômico-filosóficos de 1844. Além do mais, o volume dos Anais do Instituto Giangiacomo Feltrinelli de 1963 (Avineri, 1997) e, sobretudo, o de 1964/65 (Bell, 1959), que foi inteiramente dedicado ao "Marx jovem", representaram uma das mais importantes publicações internacionais sobre o tema. As contribuições publicadas foram, no entanto, em grande parte, de estudiosos estrangeiros. Deve-se citar, por fim, o interessante volume de Mario Dal Pra A dialética de Marx: dos escritos juvenis à "Introdução à crítica da economia política" (Cf. Della Volpe, 1971), que contém, também nele, uma parte dos manuscritos parisienses.

A divulgação dos Grundrisse - os importantíssimos manuscritos econômicos de Marx de 1857-58 - que aconteceu na Alemanha em 1953 (Rossi, 1977), ${ }^{30}$ e a partir do final dos anos sessenta, na Europa e nos Estados Unidos, deslocou a atenção dos comentaristas do texto marxiano e militantes políticos das obras

${ }^{30}$ Mario Rossi, De Hegel a Marx. III. A escola hegeliana. ([1963] 1977). Os Manuscritos econômico-filosóficos de 1844 foram analisados nas páginas 456-584. juvenis para o "novo" inédito. Nos anos oitenta, período em que a Marx-Forschung (a pesquisa sobre Marx) vivenciou um forte esvaziamento, surgiram, no entanto, alguns estudos sobre a relação entre Hegel e Marx, nos quais os manuscritos parisienses tiveram importância crucial. Dentre tais estudos, citamos Pour lire Hegel et Marx (Instituto Giangiacomo Feltrinelli, 1964) ${ }^{31}$ (Para ler Hegel e Marx) e Retour sur le jeune Marx. Deux études sur le rapport de Marx à Hegel (Instituto Giangiacomo Feltrinelli, 1965) ${ }^{32}$ (O retorno do jovem Marx. Dois estudos sobre a relação de Marx com Hegel), de Solange Maercier-Josa e Dialectics of labour. Marx and his relation to Hegel (Dal Pra, 1977) de Cristopher Arthur. Trata-se de uma demonstração do grande e permanente fascínio exercido por essas páginas. Alguns recentes estudos sobre Marx, mesmo que em número muito reduzido, se comparado ao passado, se debruçaram sobre o seu valor (Musto, 2008). ${ }^{33}$

\section{MANUSCRITOS E CADERNOS DE RESUMOS: os papéis de 1844}

Apesar da evidente incompletude e da fragmentação dos Manuscritos econômico-filo-

31 Nesse volume, havia muitos ensaios sobre "Marx e Engels. A formação do pensamento deles. O ambiente intelectual e político". Dentre eles podem ser destacados: Emile Bottigelli, Karl Marx et la gauche hégélienne; Auguste Cornu, La formation du matérialisme historique dans "L'Idéologie allemande"; Claudio Cesa, Figuras e problemas da historiografia filosófica da esquerda hegeliana. 1831-1848; Andrej Walicki, Hegel, Feuerbach and the Russian "philosophical left". 1836-1848.

$32 \mathrm{O}$ volume continha os seguintes ensaios: Adam Schaff, Découverte nouvelle de notions anciennes du marxisme; Rudolf Schlesinger, Les "Manuscrits économico-philosophiques" de Marx replacés dans leur perspective historique; Predrag Vranicki, La signification actuelle de l'humanisme du jeune Marx; Henri Lefebvre, Propositions pour une nouvelle lecture de Marx; Lucien Goldmann, Philosophie et sociologie dans l'oeuvre du jeune Marx; Iring Fetscher, La concrétisation de la notion de liberte chez Le jeune Marx; Roger Garaudy, Fichte et Marx; Ivan Dubsky, Zur Feuerbach und Marx; György Márkus, Der Begriff dês "menschlichen Wesens" in der Philosophie dês jungen Marx; Enrique Gonzáles Pedrero, O humanismo do jovem Marx. Enriquecem o volume duas importantes "Contribuicões bibliográficas": L'oeuvre de jeunesse de Marx et Engels dans lês études publiées de 1945 a 1963/64 e Marx et Engels et la gauche hégélienne (organizado por Bert Andréas).

${ }^{33}$ Uma primeira edição de 1939-41 permaneceu quase desconhecida; ver Marcello Musto, Dissemination and reception Critique of Political Economy 150 Years (2008). 
sóficos de 1844, a confusão que se seguiu às diferentes versões publicadas e, sobretudo, a consciência da ausência de grande parte do "segundo" manuscrito, o mais importante e, infelizmente perdido, ninguém, dentre os intérpretes críticos e curadores de novas edições, se ocupou em reexaminar os originais que, por aquele texto que tanto pesava no debate entre as diferentes interpretações críticas de Marx, se revelava tão necessário.

Escritos entre maio e agosto, os Manuscritos econômico-filosóficos de 1844 não podem ser considerados uma obra. Sem homogeneidade e longe de apresentarem uma estreita vinculação entre as partes, são muito mais uma evidente expressão de uma concepção teórica em fase de desenvolvimento. A forma de assimilar e utilizar as leituras de que ele se nutria fica demonstrada em um atento exame dos nove cadernos de resumos que chegaram até nós, com mais de 200 páginas de compêndios e comentários (Mercier-Josa, 1980).

Nos cadernos parisienses, foram encontrados traços do contato que Marx fez com a economia política e do processo de formação de suas primeiríssimas elaborações sobre a teoria econômica. Da comparação desses cadernos com os textos do período, publicados ou não, fica evidente a importância dessas leituras no $\stackrel{7}{\overrightarrow{2}}$ desenvolvimento de suas ideias. CircunscreN. vendo a lista somente para os autores de econo$\stackrel{8}{i}$ política, Marx elaborou resumos de textos de Say, Schüz, List, Osiander, Smith, Skarbek, Ricardo, James Mill, MacCulloch, Prevost, Destutti de Tracy, Buret, de Boisguillebert, Law e Lauderdale (Mercier-Josa, 1986). Nos Manuscritos econômico-filosóficos de 1844, nos artigos e na correspondência da época, apareceram referências a Proudhon, Schulz, Pecquer, Loudon, Sismond, Ganihl, Chevalier, Malthus, de Pompery e Bentham (Arthur, 1986).

Marx elaborou os primeiros excertos a partir do Traité d'économie politique de Say (Cf. Khan, 1995; Oishi, 2001; Rockmore, 2002), do qual transcreveu partes inteiras, enquanto assimilava conhecimentos elementares de economia. A única anotação é posterior e, como estava habituado a fazer, se concentra na parte direita da folha destinada a essa função. Mesmo os compêndios da Recherches sur la nature et les causes de la richesse des nations de Smith (Cf. Musto, 2006), cronologicamente em seguida, buscavam a análoga finalidade de consolidar a base das noções econômicas. $\mathrm{Na}$ verdade, embora eles sejam os mais longos, não têm quase nenhum comentário. Não obstante isso, o pensamento de Marx se mostra claro pela mesma organização dos resumos e, como com frequência acontece em outras partes, pela sua maneira de colocar em contrapoposição teses divergentes de diferentes economistas. Apresentam um caráter diferente, porém, os resumos de Des principes de l'économie politique et de l'impôt de Ricardo, ${ }^{34}$ nos quais surgem suas primeiras observações. Elas se concentram nos conceitos de valor e preço, concebidos ainda como perfeitamente idênticos. A igualdade entre valor e preço das mercadorias parte do conceito inicial de Marx, que conferia realidade só para o valor de troca produzido pela concorrência, deixando o preço natural na esfera da abstração. Dando continuidade aos estudos, as notas críticas não foram mais esporádicas, mas se intercalaram nos resumos das obras, aumentando, com o avanço do conhecimento, de autor para autor. Frases isoladas, depois considerações mais longas, até que, concentrando-se, nos Élemens d'économie politique de James Mill, na crítica da intermediação do dinheiro como completo domínio da coisa alienada ao homem, a relação se inverteu, e não foram mais seus textos que se intercalavam aos resumos, mas ocorreu exatamente o oposto (Cf. Marx, 1998). ${ }^{35}$

Por fim, para evidenciar, mais uma vez, a importância dos resumos, convém destacar que eles foram utilizados mesmo após terem

\footnotetext{
${ }^{34}$ Naquele período as obras dos economistas ingleses foram lidas por Marx em francês.

${ }^{35}$ Nos textos que Marx possuía em sua biblioteca pessoal e naqueles que tinha intenção de adquirir, veja Karl Marx, "Notizbuch aus den Jahren 1844-1847", MEGA ${ }^{2}$ IV/3 (1998).
} 
sido redigidos. Parte deles foi publicada em 1844, no Vorwärts!, o bi-semanal dos emigrados alemães em Paris, para auxiliar na formação intelectual dos leitores (Cf. Marx, 1981a). Sobretudo, por serem muito abrangentes, foram depois utilizados por Marx, que tinha o hábito de reler suas anotações de tempos em tempos, para a composição dos Grundrisse, manuscritos de 1861-63, conhecidos mais como Teorias sobre o mais valor, e do primeiro livro de O capital (Cf. Marx, 1981b).

Concluindo, Marx desenvolveu seus pensamentos tanto nos Manuscritos econômico-filosóficos de 1844 quanto nos cadernos de resumos de suas leituras. Os manuscritos estão repletos de citações, e o primeiro é quase uma coletânea. Os cadernos de compêndios, mesmo que sobremaneira voltados para os textos que lia, são acompanhados de seus comentários. O conteúdo de ambos, a forma de escrita - caracterizada pela divisão das folhas em colunas -, a numeração das páginas e o momento da anotação confirmam que os Manuscritos econômico-filosóficos de 1844 não são uma obra isolada, mas uma parte da sua produção crítica que, nesse período, se caracteriza pelos resumos dos textos que estudava, pelas reflexões críticas a respeito deles e pelas elaborações que, espontaneamente ou fruto de raciocínio, fixava no papel (Cf. Marx, 1981c). ${ }^{36}$ Separar esses manuscritos do resto, retirá-los de seu contexto, pode induzir a erros de interpretação (Marx, 1981d; Marx; Engels, 1976; Cf. Rojanh, 1983).

O conjunto dessas notas e a reconstituição histórica de seu amadurecimento mostram o itinerário e a complexidade de seu pensamento crítico durante esse intenso período de trabalho (Cf. Grandjonc, 1974). ${ }^{37}$ Os Manuscritos econômico-filosóficos de 1844 e os cadernos de resumos e anotações constituem o início do estudo crítico da nova disciplina com a qual Marx se firmou: a economia política. Eles estão

${ }^{36}$ Karl Marx, Exzerpte aus David Ricardo: des príncipes de l'économie politique et de l'impôt; tradução para o italiano na obra A descoberta da economia (1990).

${ }^{37}$ Veja a carta de K. Marx para H. Börnstein, escrita no mais tardar em novembro de 1844, em Marx Engels Obras (1972). cheios de elementos teóricos derivados de antecessores e contemporâneos. As observações que ele desenvolveu não foram, pois, o fruto de uma súbita intuição, mas o primeiro resultado de um intenso estudo. A hagiografia marxista-leninista dominante no passado, apresentando o pensamento de Marx com uma urgência impraticável e pré-organizando um resultado final de forma instrumental, maculou o percurso para conhecê-lo e tornou a reflexão mais pobre. É necessário, pois, reconstruir a gênese, as influências intelectuais e as conquistas teóricas dos trabalhos de Marx, evidenciando a complexidade e a riqueza de uma obra que ainda contribui para o pensamento crítico dos nossos dias.

Recebido para publicação em 02 de março de 2018 Aceito em 18 de março de 2019

\section{REFERÊNCIAS}

ADORATSKIJ, V. Einleitung. In: MEGA 1/3. Berlin: MarxEngels-Verlag, 1932.

ALTHUSSER, L. Para Marx. Roma: Editori Riuniti, 1967. p. 35-37.

. Per Marx. [1965]. Roma: Editori Riuniti, 1970.

"L'objet Du Capital". [1965]. In: . Ler o Capital. Milão: Feltrinelli, 1971.

ARTHUR, C. J. Dialectics of labour. Marx and his relation to Hegel. Oxford: Basil Blackwell, 1986.

AVINERI, S. O pensamento politico e social de Marx. [1968]. Bologna: Il Mulino, 1997.

AXELOS, K. Marx pensador da técnica. [1961]. Milão: Sugar, 1963.

BALIBAR, E. "O conceito de "ruptura epistemológica" de Gastón Bachelard a Louis Althusser". In:

Althusser. Roma: Manifestolibri, 1991. p. 65-97.

BEDESCHI, G. Alienação e fetichismo no pensamento de Marx. Bari: Laterza, 1968.

BELL, D. The "rediscovery" of alienation - Some notes along the quest for the historical Marx. The journal of Philosophy, v. 24, p. 935-944, 1959.

BIGO, P. Marxismo e humanismo. [1954]. Milão: Bompiani, 1963.

BOTTIGELLI, E. Presentation. In: MARX, K. Manuscrits de 1844. Paris: Editions Sociales, 1962. p. 66-69.

BROUCHLINSKI, V. Note sur l'histoire de la redaction et de la publication des "Manuscrits economico-philosophiques" de Karl Marx. Recherches Internationales à la lumiere du marxisme: Sur le jeune Marx, n. 19, V-VI, 1960.

BUHR, M. Entfremdung - philosophische Antropologie Marx Kritik. "Deutsche Zeitshrift für Philosophie", n. 7, p. 806-834, 1966. 
CALVEZ, J. Y. O pensamento de Karl Marx. [1956]. Torino: Borla, 1966.

CORNU, A. Karl Marx: l'homme et l'oeuvre. De l'hégélianisme au matérialisme historique. Paris: Felix Alcan, 1934.

. Marx e Engels. [1955]. Milão: Feltrinelli, 1962a.

Karl Marx et Friendich Engels. Marx a Paris. Paris: PUF, 1962b.

Einleitung. In: MARX, K. Die ökonomischphilosophische Manuskripte. Berlim: Dietz Verlag, 1968.

DAL PRA, M. La dialética em Marx: dos escritos juvenis à "introdução à crítica da economia política". Roma: Laterza. 1977.

DELLA VOLPE, G. Rousseau e Marx. [1956]. Roma: Editori Riuniti, 1971. p. 150.

ENGELS, F. Per la quarta edizione. In: MARX, K. Il capitale. Roma: Editori riuniti, 1964.

FARACOVI, O. P. O marxismo francês contemporaneo entre a dialética e a estrutura (1945-1968). Milâo: Feltrinelli, 1972.

FETSCHER, I. Marx e o marxismo: da filosofia do proletariado à Weltanschauung proletária. Firenze: Sansoni, 1969. p. 312.

FROMM, E. Marx's concepto f Man. New York: Frederick Ungar Publishing, 1961. p. 5.

GARAUDY, R. Do anátema ao diálogo. Brescia: Queriniana, 1969.

GRANDJONC, J. Marx et les communistes allemands à Paris 1844. Paris: Maspero, 1974.

HEGEL, G. W. F. Jenenser Logik, metaphysik und naturphilosophie. Organizado por G. Lasson. Leipzig: Felix Meiner, 1923.

Jenenser Realphilosophie. Organizado por J. Hoffmeister. Leipzig: Felix Meiner, 1931. v. 2.

HOMMES, J. O eros da técnica. [1955]. Roma: Abete, 1970.

HOOK, S. Towards an understanding of Karl Marx. London: Gollanz, 1933.

HYPPOLITE, J. Ensaios sobre Marx e Hegel. Milão: Bompiani, 1963. p. 153, 155.

IINSTITUTO GIANGIACOMO FELTRINELLI. Annali 1963. \& Milano: Feltrinelli, 1964.

$\dot{8}$ _. Annali 1964/65. Milano: Feltrinelli, 1965.

KHAN, N. Development of the concept and theory of alienation in Marx's writings. March 1843 to August 1844. $\Sigma$ Oslo: Solum Forlag, 1995.

$\stackrel{\infty}{\exists}$ KOJÈVE, A. Introdução à leitura de Hegel. Edição italiana †ै organizada por Franco Frigo. Milão: Adelphi Edizioni, के 1996.

¿. LANDSHUT, S. Karl Marx. Lübeck: Verlag Von Charles $\oplus$ Coleman, 1932.

¿ LANDSHUT, S.; MAYER, J. P. Vorwort. In:

i (Org.). Karl Marx: Der historische Materialismus. Die m Frühschriften. Leipzig: Kröner, 1932a.

. (Org.). Karl Marx: Der historische Materialismus. Die Frühschriften. Leipzig: Kröner, 1932b.

त్ LANGSET, L. R. Young Marx and Alienation in Western क Debate. "Inquiry", n. 1, 1963. LAPIN, N. Der junge Marx. Berlim: Dietz Verlag, 1974. p. 304.

LEFEBVRE, H. Le marxisme et la pensée française. "Les temps modernes", n. 137-138, 1957.
LÖWITH, K. De Hegel a Nietzsche: a ruptura revolucionária no pensamento do século XIX. Torino: Einaudi, 1949.

LUKÁCS, G. O jovem Hegel e os problemas da sociedade capitalista. Torino: Einaudi, 1950. p. 760.

. Lukács on his life and work. New left review, n. 68, juli/aug, 1971a.

Prefácio para a história e consciência de classe. Milão: Sugar Editore, 1971b. p. 25.

MAN, H. de. Der neu entdeckte Marx. "Der Kampf”, n. 5-6, 1932.

MANDEL, E. Dos Manuscritos de 1844 aos Grundrisse: de uma concepção antropológica a uma concepção histórica da alienação". In: .A formação do pensamento econômico de Karl Marx. [1967]. Bari: Laterza, 1970. p. 171-202.

. La formazione del pensiero economico di Karl Marx. Roma: Laterza, 1973. p. 175.

MARCUSE, H. Marxismo e revolução: estudos 1929-1932. Totino: Enaudi, 1975. p. 100.

. Razão e revolução: Hegel e o surgimento da "teoria social". Bolonha: Il Mulino, 1997.

MARX, K. Podgotovitel'nye raboty dlja "Svjatovo Semejstva”. In: RJAZANOV, D. Archiv K. Marksa i F. Engel'as. Moskva: Leningrad, 1927. p. 247-286 - p. 103142.

Notes sur le communisme et la propriété privée. La revue marxiste, n. 1, p. 6-28, fevr. 1929a.

. Notes sue les besoins, la production et la division du travail. Revue marxiste, n. 5, juin. 1929b.

. Podgotovitel'nye raboty dlja "Svjatovo Semejstva". In: MARX, K.; ENGELS, F. Sob os cuidados de David Rjazanov. Sočinenija. Moskva: Leningrad, 1929c. v. 3, p. 613-670.

Kritik der Hegelschen Dialektik und der Philosophie überhaupt. Unter dem Banner des Marxismus, n. 3, p. 256-275, 1931.

. Nationalökonomie und philosophie: über den zusammenhang der nationalökonomie mit staat, recht, moral, und bürgerlichem leben (1844). In: LANDSHUT, S.; MAYER, J. P. (Org.). Der historische materialismus. Die Frühschriften. Leipzig: Kröner, 1932a. p. 283-375.

. Ökonomischi-philosophisce manuskripte aus dem jahre 1844. In: MEGA I/3. Berlin: Marx-Engels-Verlag, 1932b. p. 29-172.

Nationalökonomie und Philosophie. Köln: Berlim: $\overline{\text { Kiepenheuer, } 1950 .}$

. Die Frühschriften. Hrsg. v. S. Landshut. Stuttgart: Kröner Verlag, 1953.

Manuscritos econômico-filosóficos de 1844. Torino: Einaudi, 1968. p. 3.

Manuscritos econômico-filosóficos de 1844. In: MARX, K.; ENGELS, F. Obras. Roma: Editori Riuniti, 1976. v. 3.

. Exzerpte aus Jean Baptiste Say: traité d'économie politique. In: MEGA² IV/2. Berlim: Dietz Verlag, 1981a. p. 301-327.

- Exzerpte aus Adam Smith: recherches sur la

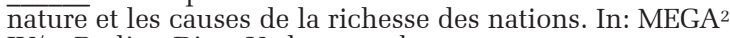
IV/2. Berlim: Dietz Verlag, 1981b. p. 332-386.

Exzerpte aus David Ricardo: des príncipes de l'économie politique et de l'impôt. In: MEGA² IV/2. Berlim: Dietz Verlag, 1981c. p. 392-427.

Exzerpte aus James Mill: élémens d'économie 
politique. In: MEGA² IV/2. Berlim: Dietz Verlag, 1981d. p. 428-470.

. A descoberta da economia. Roma: Editori Riuniti, 1990. p. 5-19.

. Notizbuch aus den Jahren 1844-1847. In: MEGA ${ }^{2}$ IV/3. Berlim: Dietz Verlag, 1998. p. 5-10, 12-13, 483-487.

MARX-ENGELS-GESAMTAUSGABE MEGA² I/2. Berlim: Dietz Verlag, 1982. p. 187-322 e 323-438.

MARX, K.; ENGELS, F. Kleine ökonomische Schriften. Berlim: Dietz Verlag, 1955. p. 42-166.

. Iz rannikh proïzvedennij. Moscou: Marx-Engels$\overline{\text { Verlag, }}$ 1956. p. 519-642.

Werke, Ergänzungsband. Erster Teil. Berlin: Dietz $\overline{\text { Verlag, }}$ 1968. p. 465-588.

Sočinenija. Mosca: [S.n.], 1974. v. 42, p. 41-174.

. Obras. Roma: Editori Riuniti, 1976. v. 3.

MAYER, J. P. Über eine unverössentlichte Schrift von Karl Marx. "Rote Revue", p. 154-157, 1931.

McLELLAN, D. Marx antes do marxismo. Torino: Einaudi, 1974. p. 189.

. Marx. Bolonha: Il Mulino, 1998. p. 84.

MENDE, G. Karl Marx' Entwicklung von revolutionären Demokraten zum Kommunisten. Berlim: Dietz Verlag, 1960. p. 132.

MERCIER-JOSA, S. Pour lire Hegel et Marx. Paris: Editions sociales, 1980.

. Pour sur le jeune Marx. Deux études sur le rappport de Marx à Hegel. Paris: Meridiens Klincksieck, 1986.

MERLEAU-PONTY, M. Sentido e não-sentido. Milão: Il Saggiatore, 1962.

MESZAROS, I. A teoria da alienação em Marx. London: Oxford University Press, 1970.

MILL, J. Élémens d'économie politique. In: MARX, K.; ENGELS, F. Obras. Roma: Editori Riuniti, 1976. p. 229-248.

MUSTO, M. Marx em Paris: a crítica de 1844. In:

(Org.). Na trilha de um fantasma. A obra de Karl Marx entre filologia e filosofia. [2005]. Roma: Manisfestolibri, 2006. p. $161-178$.

Dissemination and reception critique of political economy 150 years later. London: New York Routledge, 2008. p. 179-188.

NAVILLE, P. Da alienação à fruição. Gênese da sociologia do trabalho em Marx e Engels. O novo Leviatã. [1957]. Milão: Jaca Book, 1978.

OISHI, T. The unknown Marx. London: Pluto, 2001.
OLLMAN, B. Alienation. Marx's conception of man in capitalist society. New York: Cambridge University Press, 1971.

PAJITNOV, L. Les "Manuscrits économico-philosophiques de 1844". Recherches Internationales à la lumière du marxisme: sur le jeune Marx, ano 4, n. 19, mai./jun. 1960.

(83) PAJITNOV, L. Les "Manuscrits èconomicophilosophiques de 1844". Sur le jeune Marx, op. cit., p. 98. POPITZ, H. Der entfremdete Mensch. Zeitkritk und Geschichtsphilosophie des jungen Marx. [1953]. Darmstadt: Wissenschastliche Buchgesellschaft, 1967.

ROCKMORE, T. Marx after Marxism. Oxford: Blackwell Publishing, 2002.

ROJAHN, J. O caso dos chamados "manuscritos econômico-filosóficos do ano 1844". Passado e presente, ano 2 , n. 3, p. 43,1983 .

The emergence of a theory: the importance of Marx's notebooks exemplified by those from 1844 Rethinking marxism, v. 14, n. 4, p. 33, 2002.

ROSENBERG, D. I. Die entwicklung der ökonomischen Lehre von Marx und Engels in den vierziger Jahren des 19. Jahrhunderts. Berlin: Dietz, 1958.

ROSSI, M. De Hegel a Marx. A escola hegeliana. O jovem Marx. [1963]. Milano: Feltrinelli, 1977.

RUBEL, M. Introduction. In: MARX, K. Oeuvres: economie. Paris: Gallimard, 1968. v. 2.

Karl Marx: ensaio de biografia intelectual. Prolegômenos para uma Sociologia ética. Milão: Colibri, 2001. p. 130.

SÈVE, L. Penser avec Marx aujourd'hui. I. Marx et nous. Paris: La Dispute, 2004.

SCHAFF, A. A alienação como fenômeno social. Roma: Editori Riuniti, 1979.

SUR LE JEUNE MARX. Recherches Internationales à la lumière du marxisme. Paris: Editions de la Nouvelle Critique, 1961. N. Especial.

THIER, E. Die Anthropologie des jungen Marx nach den Pariser ökonomisch-philosophischen Manuskripten, Einführung. In: MARX, K. Nationalökonomie und Philosophie. Köln-Berlin: Kiepenheuer, 1950.

Das Menschenbild des jungen Marx. Göttingen: Vandenhoeck \& Ruprecht, 1957.

TOGLIATTI, P. Da Hegel au marxisme. Sur le jeune Marx "Recherches internationales à la lumiere du marxisme", 1961.

TUCHSCHEERER, W. Antes do "Capital": a formação do pensamento econômico de Marx. (1843/1858). [1968]. Firenze: La Nuova Italia, 1980.

TUCKER, R. C. Philosophy \& Myth in Karl Marx. [1961]. New Brunswick: London: Transaction Publishers, 2001. 


\section{THE ECONOMIC AND PHILOSOPHIC MANUSCRIPTS OF 1844 BY KARL MARX: publishing difficulties and critical interpretations}

\section{Marcello Musto}

The Economic and Philosophic Manuscripts of 1844 constitute one of Karl Marx's most renowned and widespread writings worldwide. However, this much debated and present in the Marxist debates' text, remained unknown for a long time. The instrumental readings which different groups made on the Economic and Philosophic Manuscripts of 1844 are a clear example of how Marx's work was constantly the object of theoretical-political conflict. To better highlight this reality, the second and third paragraphs of this article reconstruct the editorial difficulties associated with its publication. The fourth, fifth and sixth paragraphs, however, provide a brief review. A philological analysis of the Economic and Philosophic Manuscripts of 1844 based on the new historical-critical MEGA edition was developed in the seventh and eighth paragraphs. In the conclusion, follows a table that reconstructs the chronology of the elaboration of the manuscripts and notebooks of excerpts of the period.

Keywords: EPM of 1844, Young Marx, Marxism, Alienation, MEGA.

\section{LES MANUSCRITS ÉCONOMICO- PHILOSOPHIQUES DE KARL MARX DE 1844: Les difficultés pour l'édition et les interprétations critiques}

\author{
Marcello Musto
}

Les manuscrits économico-philosophiques de 1844 constituent l'un des écrits les plus célèbres et les plus répandus de Karl Marx dans le monde. Ce texte si controversé et si présent dans les débats marxistes est cependant resté longtemps méconnu. La compréhension des textes des Manuscrits économico-philosophiques de 1844, réalisée par l'un ou l'autre groupe, montre bien la manière dont les travaux de Marx ont constamment fait l'objet de conflits théorico-politiques. Pour mieux souligner cette réalité les deuxième et troisième paragraphes de cet article reconstituent les difficultés de rédaction liées à la publication de son œuvre. Les quatrième, cinquième et sixième paragraphes en présentent toutefois un bref aperçu. Une analyse philologique des Manuscrits économicophilosophiques de 1844 est présentée dans les septième et huitième paragraphes sur la base de la nouvelle édition historique et critique MEGA. Dans la conclusion un tableau reconstruit la chronologie de l'élaboration des manuscrits et des cahiers d'extraits de la période.

Mots-CLÉs: Manuscrits économico-philosophiques de 1844, le jeune Marx, Aliénation, MEGA. Autor de: Ripensare Marx e i marxismi. Studi e saggi (Carocci, 2011); Another Marx: Early Manuscripts to the International (Bloomsbury, 2018); Karl Marx. Biografia intellettuale e politica 1857-1883 (Einaudi, 2018); The Travels of Karl Marx (Europa Editions, 2020); e The Last Years of Karl Marx: An Intellectual Biography (Stanford University Press, 2020). Entre seus volumes editados estão: Karl Marx’s Grundrisse: Foundations of the Critique of Political Economy 150 Years Later (Routledge, 2008); Marx for Today (Routledge, 2012); Workers Unite! The International 150 Years Later (Bloomsbury, 2014); The International After 150 Years: Labour Versus Capital, Then and Now (com George Comninel e Victor Wallis, Routledge, 2015); Marx's Capital after 150 Years: Critique and Alternative to Capitalism (Routledge, 2019); Karl Marx's Life, Ideas, Influences: A Critical Examination on the Bicentenary (com Shaibal Gupta e Babak Amini, Palgrave, 2019); The Marx Revival: Key Concepts and New Critical Interpretations (Cambridge University Press, 2020, no prelo); e The Routledge Handbook of Marx's 'Capital': A Global History of Translation, Dissemination and Reception (com Babak Amini, Routledge, 2020, no prelo). Seus artigos apareceram em muitas revistas, incluindo as revistas International Review of Social History, Science \& Society, Critique, Review of Radical Political Economics, Socialism and Democracy, Economic \& Political Weekly, e Contemporary Sociology. Seus escritos - disponíveis em www.marcellomusto.org foram publicados mundialmente em mais de vinte idiomas. Ele também é o editor da série Marx, Engels, Marxisms (com Terrell Carver, Palgrave). 